\title{
PEMBOBOTAN KRITERIA SISTEM PENDUKUNG KEPUTUSAN PEMILIHAN BIDANG PEMINATAN MENGGUNAKAN METODE ANALYTIC HIERARCHY PROCESS (STUDI KASUS: PROGRAM STUDI SISTEM INFORMASI UNIVERSITAS TELKOM)
}

\author{
${ }^{1}$ Ayu Cahyani Febryanti, ${ }^{2}$ Irfan Darmawan, ${ }^{3}$ Rachmadita Andreswari \\ 1,2,3 Program Studi Sistem Informasi, Fakultas Rekayasa Industri, Telkom University \\ ${ }^{1}$ ayucahyani96@gmail.com, ${ }^{2}$ dirfand@gmail.com, ${ }^{3}$ andreswari@gmail.com
}

\begin{abstract}
Abstrak-Pemilihan bidang peminatan bagi mahasiswa Program Studi Sistem Informasi Universitas Telkom merupakan hal yang penting, namun masih dirasa sulit. Dalam menyelesaikan permasalahan tersebut, diperlukan penelitian mengenai pemodelan sistem pendukung keputusan pemilihan bidang peminatan. Pembuatan sistem pendukung keputusan ini dapat menggunakan berbagai metode, salah satunya yang dapat diterapkan adalah metode Simple Additive Weighting (SAW). Metode ini mampu menentukan solusi berdasarkan peringkat preferensi alternatif solusi tertinggi. Selain itu, perhitungan komputasi pada metode ini relative singkat, jika dibandingkan dengan metode lainnya. Metode SAW yang digunakan tidak ada perhitungan bobot kriteria secara matematis. Untuk mendapatkan nilai bobot setiap kriteria digunakan matriks perbandingan berpasangan dari metode analytic hierarchy process (AHP). Penelitian ini menghasilkan bobot kriteria nilai mata kuliah sebesar $65 \%$ dan bobot kriteria potensi kecenderungan sebesar 35\%, dengan konsistensi rasio dibawah $10 \%$. Hasil perhitungan bobot digunakan pada penelitian pemodelan sistem pendukung keputusan pemilihan bidang peminatan dengan metode SAW pada Program Studi Sistem Informasi Universitas Telkom.
\end{abstract}

Kata kunci: bidang peminatan, sistem pendukung keputusan, analytic hierarcy process

\section{PENDAHULUAN}

Sebagai mahasiswa Program Studi Sistem Informasi Universitas Telkom diharuskan untuk memilih satu dari tujuh bidang peminatan yang disediakan. Pemilihan bidang peminatan ini dilakukan pada awal semester 5 dan akan berkaitan dengan pengambilan tugas akhir mahasiswa. Program Studi Sistem Informasi Universitas Telkom memiliki Kelompok Keahlian (KK) dengan total tujuh bidang peminatan didalamnya. Kelompok keahlian ESD (Enterprise System Development) dengan bidang peminatan Enterprise System Development: Information System Developer, Enterprise Data Management: Data Specialist, dan Technopreneurship. Kelompok keahlian ESA (Enterprise Solution \& Assurance) dengan bidang peminatan Enterprise Resource Planning: ERP Specialist, Information System Management: IS Consultant/Auditor, Enterprise Architecture: Enterprise Architect, dan Enterprise Infrastructure: Network Specialist. Bidang peminatan ini merupakan salah satu bentuk fasilitas yang disediakan program studi guna menghasilkan lulusan Sistem Informasi yang berkualitas tinggi, berkompetensi, dan memiliki keahlian khusus di bidang Sistem Informasi. Sehingga lulusan Sistem Informasi diharapkan mampu merancang sistem informasi yang efektif, efisien, serta sesuai dengan kebutuhan organisasi.

Berdasarkan pengumpulan data melalui kuesioner dengan responden mahasiswa program studi Sistem Informasi Universitas Telkom sebanyak 49 responden. Didapatkan informasi bahwa masih ada mahasiswa yang belum mengetahui kelompok keahlian, serta menemukan kesulitan dalam menentukan pilihan bidang peminatan. Responden menyetujui akan adanya sebuah sistem pendukung keputusan pemilihan bidang peminatan. Kriteria nilai matakuliah dan potensi kecenderungan disetujui membantu memilih bidang peminatan.

Pada penentuan bobot menggunakan metode AHP ini kriteria nilai mata kuliah dan potensi kecenderungan akan menjadi kriteria utama. Kriteria disusun menjadi hirarki dengan tujuan utama, kriteria, sub kriteria, dan alternatif solusi [1]. Sub kriteria dari kriteria nilai mata kuliah adalah nilai mata kuliah information system development (ISD), nilai mata kuliah enterprise data management (EDM), nilai mata kuliah technopreneurship (TEC), nilai mata kuliah enterprise resource planning (ERP), nilai mata kuliah enterprise architecture (EA), nilai mata kuliah information system management (ISM), nilai mata kuliah network specialist (NS). Sub kriteria dari kriteria potensi kecenderungan adalah pilihan karir, pengetahuan dasar sistem informasi, dan kemampuan umum. Sub kriteria penegtahuan dasar sistem informasi memiliki sub kriteria, yaitu pengelolaan data, analisa sistem, 
fungsionalitas sistem informasi, dasar sistem informasi, dan infrastruktur teknologi informasi. Dan untuk alternatif solusi yang digunakan, yaitu Enterprise System Development: Information System Developer, Enterprise Data Management: Data Specialist, Technopreneurship, Enterprise Resource Planning: ERP Specialist, Information System Management: IS Consultant/Auditor, Enterprise Architecture: Enterprise Architect, dan Enterprise Infrastructure: Network Specialist.

Penelitian sebelumnya mengenai sistem pendukung keputusan pemilihan bidang peminatan menggunakan metode berbeda, seperti pada penelitian Aplikasi Pembantu Pengolahan Informasi Perminatan Topik TA dan KK Bagi Mahasiswa Fakultas Informatika Institut Teknologi Telkom. Hasil penelitian menunjukkan sistem pendukung keputusan yang dibangun dapat memberikan informasi terkait kelompok keahlian, mahasiswa dapat melihat dan memilih topik tugas akhir yang ditawarkan oleh dosen, dan mahasiswa mendapatkan rekomendasi topik tugas akhir yng sesuai dengan hasil peminatan. Dalam hal ini hasil penelitian didapatkan menggunakan metode MAUT (Multi Attribute Utility Theory) dengan 2 kriteria, yaitu nilai mata kuliah wajib dan kuesioner minat dengan bobot masing-masing 0.7 dan $0.3[2]$.

Penelitian Sistem Pendukung Keputusan Untuk Penjurusan Mahasiswa (Studi Kasus: Teknik Informatika Universitas Bunda Mulia) dengan hasil sistem yang dibangun dapat membantu mahasiswa dalam memilih bidang peminatan. Dalam hal ini hasil pengujian menunjukan bahwa berdasarkan input nilai mahasiswa, sistem akan menghitung persentase kecocokan masing-masing bidang peminatan sesuai dengan rating kecocokan dari setiap alternatif dan range nilai mata kuliah. Sehingga input dari nilai mahasiswa akan menghasilkan rekomendasi bidang peminatan [3]. Penelitian penentuan kriteria menggunakan metode AHP dengan judul Identifikasi Key Position dengan Metode Analytic Hierarchy Process (AHP) dan Kriteria Profil Kompetensi Talent Key Position pada PT Industri Telekomunikasi Indonesia. Identifikasi key position pada penelitian ini menggunakan pembobotan dari metode AHP untuk posisi manager dan supervisior berdasarkan kriteria yang telah didefinisikan. Hasil dari penelitian ini berupa 18 key position dengan 3 kriteria talent tambahan untuk manager dan 4 kriteria tambahan untuk supervisior [4].

\section{STUDI LITERATUR}

A. Sistem Pendukung Keputusan (SPK)

Sistem pendukung keputusan merupakan sebuah sistem yang dibangun dengan tujuan mendukung pengambilan keputusan pada permasalahan tidak terstruktur maupun semiterstruktur. Sebuah sistem pendukung keputusan dapat mendukung analisis ad hoc data dan pemodelan keputusan, yang berorientasi pada perencanaan masa depan yang digunakan pada waktu yang tidak biasa dan retang waktu yang tidak dapat ditentukan [5]. Sistem pendukung keputusan merupakan sistem berbasis komputer yang mengandung interaksi 3 komponen yaitu, bahasa, pengetahuan, serta pengolahan masalah [6]. Beberapa tujuan dari sebuah sistem pendukung keputusan menurut Turban [7], diantaranya:

a) Membantu pengambilan keputusan untuk pemasalahan semi terstruktur.

b) Sebagai pemberi dukungan atas pertimbangan manajer dalam pengambilan keputusan.

c) Untuk meningkatkan efektivitas keputusan yang diambil.

d) Mempercepat pengambilan keputusan, karena menggunakan proses komputasi.

e) Meningkatkan kualitas keputusan yang diambil.

B. Komponen Sistem Pendukung Keputusan

Sistem pendukung keputusan terdiri atas empat komponen, yaitu [8]:

a) Subsistem manajemen data

Memasukkan satu database yang berisi data yang sesuai dengan situasi dan dikelola oleh sistem manajemen.

b) Subsistem manajemen model

Perangkat lunak yang memasukkan model yang memberikan kapabilitas analitik dan manajemen yang tepat.

c) Subsistem antarmuka pengguna Perangkat lunak yang berkomunikasi dengan pengguna.

d) Subsistem manajemen berbasis pengetahuan Subsistem yang mendukung subsistem lain, memberikan pengetahuan bagi pengambil keputusan dalam memperbesar ruang lingkup pengetahuan.

C. Metode Analitycal Hierarchi Process (AHP)

Metode Analytical Hierarchy Process (AHP) merupakan salah satu metode pendukung keputusan MADM yang dikembangkan pada tahun 1980 oleh Thomas L., Saaty. Pada metode ini permasalahan yang ada diuraikan kedalam bentuk hirarki, hirarki yang dibuat terdiri atas beberapa tingkatan dimulai dengan tujuan, kriteria, dan alternatif. Langkahlangkah dalam melakukan perhitungan pada metode AHP, diantaranya [1][9]:

a. Mendefinisikan permasalahan dan menentukan solusi yang ingin dibuat.

b. Membuat struktur hirarki, dalam struktur hirarki ini akan disusun dari level teratas sampai terbawah. Level teratas hirarki merupakan tujuan, lalu kriteria pengambil keputusan, sub-kriteria, dan terakhir alternatif solusi.

c. Membuat matriks perbandingan berpasangan, kriteria yang telah didefinisikan akan diberi bobot dan dibandingkan berpasangan dalam bentuk matriks. Pada matriks ini akan ditentukan prioritas solusi.

d. Mendefinisikan perbandingan berpasangan.

e. Menghitung nilai eigen dari matriks perbandingan berpasangan, perhitungan nilai eigen ini dapat dilakukan dengan 2 cara, yaitu:

1. Mengkuadratkan matriks hasil perbandingan, lalu hitung jumlah nilai dari setiap baris dan lakukan normalisasi matriks.

2. Menjumlahkan nilai dari setiap kolom pada matriks perbandingan berpasangan, lalu bagi setiap nilai pada kolom dengan jumlah total kolom terkait untuk 
mendapatkan normalisasi matriks. Setelah itu jumlahkan nilai dari setiap baris dan bagi dengan jumlah elemen untuk mendapatkan nilai rata-rata.

f. Menghitung nilai vektor eigen dari masing-masing matriks perbandingan berpasangan, nilai eigen yang dihasilkan merupakan bobot dari setiap elemen yang akan digunakan untuk menentuka prioritas elemen pada struktur hirarki terbawah sampai mencapai struktur hirarki teratas.

g. Memeriksa konsistensi hirarki, pada langkah ini rasio konsistensi dihitung dengan indeks konsistensi. Konsistensi rasio dikatakan benar jika hasilnya kurang dari sama dengan $10 \%$, dan dikatakan salah jika hasilnya lebih dari $10 \%$, jika hal ini terjadi maka penilaian data perlu diperbaiki dan ditinjau ulang [10][11].

Untuk menghitung Consistency Indeks (CI) dapat menggunakan rumus [12]:

$\mathrm{CI}=\frac{(\lambda \text { maks }-\mathrm{n})}{n-1}$

Dengan $\mathrm{n}=$ banyaknya elemen

Untuk menghitung Consistency Ratio (CR) dapat menggunakan rumus [12] :

$$
\mathrm{CR}=\frac{\mathrm{CI}}{I R}
$$

Dengan IR = indeks random consistency yang dapat dilihat pada Tabel I [13],

Tabel I

Tabel Random Consistency Index (RI)

\begin{tabular}{|c|c|}
\hline Ukuran Matriks & Nilai IR \\
\hline 1,2 & 0,00 \\
\hline 3 & 0,58 \\
\hline 4 & 0,90 \\
\hline 5 & 1,12 \\
\hline 6 & 1,24 \\
\hline 7 & 1,32 \\
\hline 8 & 1,41 \\
\hline 9 & 1,45 \\
\hline 10 & 1,49 \\
\hline
\end{tabular}

D. Nilai Indeks Saaty

Dalam menyusun matriks perbandingan berpasangan nilai indeks yang diberikan pada matriks berdasarkan nilai indeks dari Saaty (2001) yang mendefinisikan skala kepentingan antara 2 kriteria [14] yang ditunjukkan pada Tabel II.

\section{E. State of the art}

Implementasi dari sebuah sistem pendukung keputusan dapat dilihat beberapa penelitian terdahulu. Seperti pada penelitian yang dilakukan oleh Mahendra dengan judul penelitian Implementasi Fuzzy Inference System Tsukamoto untuk Penentuan Topik Tugas Akhir. Kesimpulan penelitian ini adalah bahwa metode yang digunakan pada 172 sampel data memiliki tingkat akurasi lebih tinggi dibandingkan dengan metode lain. Tingkat akurasi dari hasil penelitian ini sebesar $88.39 \%$ dari uji sampel. Dalam hal ini tingkat akurasi didapatkan berdasarkan defuzzyfikasi rata-rata terpusat pada metode FIS Tsukamoto [15].

Tabel II

Tabel Nilai Indeks Saaty [14

\begin{tabular}{|c|c|c|c|c|c|}
\hline \multicolumn{6}{|c|}{ MUCRs Sady $[1]$} \\
\hline $\begin{array}{c}\text { Inde } \\
\text { ks }\end{array}$ & Definisi & Keterangan & $\begin{array}{c}\text { Inde } \\
\text { ks }\end{array}$ & Definisi & Keterangan \\
\hline 1 & $\begin{array}{c}\text { Sama } \\
\text { pentingn } \\
\text { ya }\end{array}$ & $\begin{array}{c}\text { Elemen A } \\
\text { sama } \\
\text { pentingnya } \\
\text { dengan elemen } \\
\text { B } \\
\end{array}$ & $1 / 1$ & $\begin{array}{c}\text { Sama } \\
\text { pentingny } \\
\text { a }\end{array}$ & $\begin{array}{c}\text { Elemen A } \\
\text { sama } \\
\text { pentingnya } \\
\text { dengan } \\
\text { elemen B } \\
\end{array}$ \\
\hline 2 & $\begin{array}{c}\text { Sama } \\
\text { atau } \\
\text { sedikit } \\
\text { lebih } \\
\text { penting }\end{array}$ & $\begin{array}{c}\text { Elemen A } \\
\text { sama atau } \\
\text { sedikit lebih } \\
\text { penting dari } \\
\text { elemen B }\end{array}$ & $1 / 2$ & $\begin{array}{l}\text { Sama atau } \\
\text { sedikit } \\
\text { tidak lebih } \\
\text { penting }\end{array}$ & $\begin{array}{c}\text { Elemen A } \\
\text { sama atau } \\
\text { sedikit } \\
\text { tidak lebih } \\
\text { penting dari } \\
\text { elemen B }\end{array}$ \\
\hline 3 & $\begin{array}{l}\text { Sedikit } \\
\text { lebih } \\
\text { penting }\end{array}$ & $\begin{array}{c}\text { Elemen A } \\
\text { sedikit lebih } \\
\text { penting dari } \\
\text { elemen B }\end{array}$ & $1 / 3$ & $\begin{array}{l}\text { Sedikit } \\
\text { tidak lebih } \\
\text { penting }\end{array}$ & $\begin{array}{l}\text { Elemen A } \\
\text { sedikit } \\
\text { tidak lebih } \\
\text { penting dari } \\
\text { elemen B }\end{array}$ \\
\hline 4 & $\begin{array}{c}\text { Sedikit } \\
\text { atau } \\
\text { lebih } \\
\text { penting }\end{array}$ & $\begin{array}{c}\text { Elemen A } \\
\text { berada } \\
\text { diantara } \\
\text { sedikit lebih } \\
\text { penting dan } \\
\text { lebih penting } \\
\text { dari elemen B }\end{array}$ & $1 / 4$ & $\begin{array}{c}\text { Sedikit } \\
\text { atau tidak } \\
\text { lebih } \\
\text { penting }\end{array}$ & $\begin{array}{c}\text { Elemen A } \\
\text { sedikit atau } \\
\text { tidak lebih } \\
\text { penting dari } \\
\text { elemen B }\end{array}$ \\
\hline 5 & $\begin{array}{c}\text { Lebih } \\
\text { penting }\end{array}$ & $\begin{array}{c}\text { Elemen A } \\
\text { lebih penting } \\
\text { dari elemen B }\end{array}$ & $1 / 5$ & $\begin{array}{l}\text { Tidak } \\
\text { lebih } \\
\text { penting }\end{array}$ & $\begin{array}{c}\text { Elemen A } \\
\text { tidak lebih } \\
\text { penting dari } \\
\text { elemen B }\end{array}$ \\
\hline 6 & $\begin{array}{c}\text { Jauh } \\
\text { lebih } \\
\text { penting }\end{array}$ & $\begin{array}{c}\text { Elemen A } \\
\text { berada } \\
\text { diantara lebih } \\
\text { penting dan } \\
\text { sangat penting } \\
\text { dari elemen B }\end{array}$ & $1 / 6$ & $\begin{array}{c}\text { Jauh tidak } \\
\text { lebih } \\
\text { penting }\end{array}$ & $\begin{array}{c}\text { Elemen A } \\
\text { jauh tidak } \\
\text { lebih } \\
\text { penting dari } \\
\text { elemen B }\end{array}$ \\
\hline 7 & $\begin{array}{l}\text { Sangat } \\
\text { penting }\end{array}$ & $\begin{array}{c}\text { Elemen A } \\
\text { sangat penting } \\
\text { dibandingkan } \\
\text { dengan elemen } \\
\text { B }\end{array}$ & $1 / 7$ & $\begin{array}{l}\text { Sangat } \\
\text { tidak } \\
\text { penting }\end{array}$ & $\begin{array}{c}\text { Elemen A } \\
\text { sangat tidak } \\
\text { penting } \\
\text { dibandingk } \\
\text { an dengan } \\
\text { elemen B }\end{array}$ \\
\hline 8 & $\begin{array}{c}\text { Antara } \\
\text { sangat } \\
\text { penting } \\
\text { dan } \\
\text { mutlak } \\
\text { sangat } \\
\text { penting }\end{array}$ & $\begin{array}{c}\text { Elemen A } \\
\text { terletak pada } \\
\text { posisi antara } \\
\text { sangat penting } \\
\text { dan mutlak } \\
\text { sangat penting } \\
\text { dari elemen B }\end{array}$ & $1 / 8$ & $\begin{array}{c}\text { Antara } \\
\text { sangat } \\
\text { tidak } \\
\text { penting } \\
\text { dan } \\
\text { mutlak } \\
\text { tidak } \\
\text { penting }\end{array}$ & $\begin{array}{c}\text { Elemen A } \\
\text { berada } \\
\text { diantara } \\
\text { sangat tidak } \\
\text { penting dan } \\
\text { mutlak } \\
\text { tidak } \\
\text { penting } \\
\text { daripada } \\
\text { elemen B }\end{array}$ \\
\hline 9 & $\begin{array}{c}\text { Mutlak } \\
\text { sangat } \\
\text { penting }\end{array}$ & $\begin{array}{c}\text { Elemen A } \\
\text { mutlak sangat } \\
\text { penting } \\
\text { dibandingkan } \\
\text { elemen B }\end{array}$ & $1 / 9$ & $\begin{array}{l}\text { Mutlak } \\
\text { tidak } \\
\text { penting }\end{array}$ & $\begin{array}{c}\text { Elemen A } \\
\text { mutlak } \\
\text { tidak } \\
\text { pernting } \\
\text { dibandingk } \\
\text { an dengan } \\
\text { elemen B } \\
\end{array}$ \\
\hline
\end{tabular}


Suryaningrum dengan penelitian Sistem Pendukung Keputusan Untuk Penjurusan Mahasiswa (Studi Kasus: Teknik Informatika Universitas Bunda Mulia) dengan hasil sistem yang dibangun dapat membantu mahasiswa dalam memilih bidang peminatan. Dalam hal ini hasil pengujian menunjukan bahwa berdasarkan input nilai mahasiswa, sistem akan menghitung persentase kecocokan masing-masing bidang peminatan sesuai dengan rating kecocokan dari setiap alternatif dan range nilai mata kuliah. Sehingga input dari nilai mahasiswa akan menghasilkan rekomendasi bidang peminatan [3].

Khairinisa dengan penelitian Aplikasi Pembantu Pengolahan Informasi Perminatan Topik TA dan KK Bagi Mahasiswa Fakultas Informatika Institut Teknologi Telkom, dengan hasil penelitian bahwa sistem pendukung keputusan yang dibangun dapat memberikan informasi terkait kelompok keahlian, mahasiswa dapat melihat dan memilih topik tugas akhir yang ditawarkan oleh dosen, dan mahasiswa mendapatkan rekomendasi topik tugas akhir yng sesuai dengan hasil peminatan. Dalam hal ini hasil penelitian didapatkan menggunakan metode MAUT (Multi Attribute Utility Theory) dengan 2 kriteria, yaitu nilai mata kuliah wajib dan kuisioner minat dengan bobot masing-masing 0.7 dan 0.3. Hasil perumusan bobot kriteria akan dijumlahkan dengan hasil dari identifikasi alternatif, lalu diranking sehingga akan menghasilkan data kelompok keahlian dan topik tugas akhir yang ditawarkan oleh kelompok keahlian hasil rekomendasi [2].

Penelitian penentuan kriteria menggunakan metode AHP, dengan judul Identifikasi Key Position dengan Metode Analytic Hierarchy Process (AHP) dan Kriteria Profil Kompetensi Talent Key Position pada PT.Industri Telekomunikasi Indonesia. Identifikasi key position pada penelitian ini menggunakan pembobotan dari metode AHP untuk posisi manager dan supervisior berdasarkan kriteria yang telah didefinisikan. Hasil dari penelitian ini berupa $18 \mathrm{key}$ position dengan 3 kriteria talent tambahan untuk manager dan 4 kriteria tambahan untuk supervisior [4].

\section{METODOLOGI PENELITIAN}

\section{A. Metode Pengumpulan Data}

a) Studi Pustaka

Untuk mendapatkan landasan teori pendukung sesuai dengan permasalahan yang akan diteliti, penulis melakukan studi pustaka dengan mempelajari buku referensi dan penelitian sejenis yang pernah dilakukan sebelumnya oleh peneliti lain.

b) Studi Lapangan

Studi lapangan dilakukan dengan pengumpulan data menggunakan kuisioner untuk mengumpulkan data mengenai kriteria yang akan digunakan dalam sistem.

\section{B. Metode Pengolahan Data}

Metode pengolahan data pada penelitian ini akan meggunakan algoritma AHP untuk menentukan nilai bobot kriteria pada sistem pendukung keputusan pemilihan bidang peminatan. Langkah yang dilakukan, yaitu : a. Mendefinisikan permasalahan dan solusi.

b. Membuat struktur hirarki, dalam struktur hirarki ini akan disusun dari level teratas sampai terbawah. Dimana level teratas merupakan tujuan, diikuti dengan kriteria dan sub krtiteria, dan level terbawah merupakan alternatif solusi.

c. Membuat matriks perbandingan berpasangan, kriteria yang telah didefinisikan akan diberi bobot dan dibandingkan berpasangan dalam bentuk matriks.

d. Mendefinisikan perbandingan berpasangan.

e. Menghitung nilai eigen dari matriks perbandingan berpasangan.

f. Menghitung nilai vektor eigen dari masing-masing matriks perbandingan berpasangan.

g. Memeriksa konsistensi hirarki.

\section{HASIL DAN ANALISIS}

\section{A. Mendefinisikan permasalahan dan solusi}

Permasalahan yang ingin diselesaikan dalam penelitian ini adalah pemberian bobot bagi kriteria pada pemodelan sistem pendukung keputusan pemilihan bidang peminatan. Pada penelitian pemodelan sistem pendukung keputusan pemilihan bidang peminatan menggunakan metode simple additive weighting, metode SAW tidak menyediakan proses kulitatif maupun kuantitatif yang tetap dalam menentukan bobot kriteria yang digunakan dalam sistem pendukung keputusan. Sehingga untuk mendapatkan nilai bobot dari kriteria digunakan metode AHP, yang menerapkan konsep matriks perbandingan berpasangan dengan nilai perbadingan berdasarkan nilai indeks Saaty.

\section{B. Struktur hirarki kriteria}

Tabel III

Kriteria Pendukung Keputusan

\begin{tabular}{|c|c|}
\hline $\begin{array}{c}\text { Kode } \\
\text { kriteria }\end{array}$ & Nama kriteria \\
\hline $\mathrm{C} 1$ & Nilai mata kuliah peminatan information system developer \\
\hline $\mathrm{C} 2$ & Nilai mata kuliah peminatan enterprise data management \\
\hline C3 & Nilai mata kuliah peminatan technopreneurship \\
\hline $\mathrm{C} 4$ & Nilai mata kuliah peminatan enterprise resource planning \\
\hline $\mathrm{C} 5$ & Nilai mata kuliah peminatan enterprise architecture \\
\hline $\mathrm{C} 6$ & $\begin{array}{l}\text { Nilai mata kuliah peminatan information system } \\
\text { management }\end{array}$ \\
\hline $\mathrm{C} 7$ & Nilai mata kuliah peminatan network specialist \\
\hline $\mathrm{C} 8$ & Pemilihan karir untuk masing-masing bidang peminatan \\
\hline \multirow{5}{*}{ C9 } & Kemampuan umum : tanggung jawab \\
\hline & Kemampuan umum : komunikasi \\
\hline & Kemampuan umum : negosiasi \\
\hline & Kemampuan umum : kerjasama \\
\hline & Kemampuan umum : logika \\
\hline $\mathrm{C} 10$ & Pengetahuan : dasar sistem informasi \\
\hline $\mathrm{C} 11$ & Pengetahuan : fungsionalitas sistem informasi \\
\hline $\mathrm{C} 12$ & Pengetahuan : pengelolaan basis data \\
\hline $\mathrm{C} 13$ & Pengetahuan : analisa sistem \\
\hline $\mathrm{C} 14$ & Pengetahuan : infrastruktur teknologi informasi \\
\hline
\end{tabular}


Hirarki kriteria disusun dari level teratas sampai level terbawah. Level teratas merupakan tujuan sistem pendukung keputusan lalu diikuti dengan kriteria utama dan subkriteria pada level selanjutnya [1], Kriteria yang digunakan dalam penelitian ini merujuk pada hasil kuisioner dan buku ringkasan kurikulum 2016 Program Studi Sistem Informasi Universitas Telkom. Daftar kriteria dapat dilihat pada Tabel III.

Kriteria nilai mata kuliah pada Tabel III untuk setiap bidang peminatan terdiri atas beberapa nilai mata kuliah semester 1 sampai 4 yang memiliki pengaruh terhadap peminatan terkait. Hirarki kriteria dapat dilihat pada Gambar 1, dimana tujuan sebagai hirarki teratas, diikuti kriteria utama, sub kriteria dan level terbawah hirarki merupakan alternatif solusi.

\section{Menghitung Pembobotan Kriteria}

a) Nilai bobot subkriteria nilai mata kuliah

Pembobotan untuk subkriteria nilai mata kuliah dimulai dengan mendefinisikan matriks perbandingan berpasangan, dapat dilihat pada Tabel IV. Selanjutnya matriks akan dinormalisasi, hasil normalisasi dapat dilihat pada Tabel V. Dilanjutkan dengan perhitungan vektor eigen yang dapat dilihat pada Tabel VI. Lalu dilakukan perhitungan weight sum model untuk mendapatkan nilai bobot seperti pada Tabel VII.

Tabel IV

Matriks Perbandingan Subkriteria Nilai Mata Kuliah

\begin{tabular}{|c|c|c|c|c|c|c|c|}
\hline & $\begin{array}{c}\text { NILAI } \\
\text { ISD }\end{array}$ & $\begin{array}{c}\text { NILAI } \\
\text { EDM }\end{array}$ & $\begin{array}{c}\text { NILAI } \\
\text { TEC }\end{array}$ & $\begin{array}{c}\text { NILAI } \\
\text { ERP }\end{array}$ & $\begin{array}{c}\text { NILAI } \\
\text { EA }\end{array}$ & $\begin{array}{c}\text { NILAI } \\
\text { ISM }\end{array}$ & $\begin{array}{l}\text { NILA } \\
\text { I NS } \\
\end{array}$ \\
\hline $\begin{array}{l}\text { NILAI } \\
\text { ISD }\end{array}$ & 1 & 1.9 & 4.17 & 2.9 & 3 & 2.75 & 3.14 \\
\hline $\begin{array}{c}\text { NILAI } \\
\text { EDM }\end{array}$ & $\begin{array}{c}0.5263 \\
15789\end{array}$ & 1 & 3.6 & 2.24 & 2.75 & 2.43 & 2 \\
\hline $\begin{array}{c}\text { NILAI } \\
\text { TEC }\end{array}$ & $\begin{array}{c}0.2398 \\
08153\end{array}$ & $\begin{array}{c}0.2398 \\
08153\end{array}$ & 1 & 1.51 & 0.91 & 0.73 & 1.47 \\
\hline $\begin{array}{c}\text { NILAI } \\
\text { ERP }\end{array}$ & $\begin{array}{l}0.3448 \\
27586\end{array}$ & $\begin{array}{l}0.3448 \\
27586\end{array}$ & $\begin{array}{c}0.6622 \\
51656\end{array}$ & 1 & 1.14 & 1.05 & 3 \\
\hline $\begin{array}{c}\text { NILAI } \\
\text { EA }\end{array}$ & $\begin{array}{l}0.3333 \\
33333\end{array}$ & $\begin{array}{l}0.3333 \\
33333\end{array}$ & $\begin{array}{l}1.0989 \\
01099\end{array}$ & $\begin{array}{c}0.8771 \\
92982\end{array}$ & 1 & 2.47 & 1.98 \\
\hline $\begin{array}{c}\text { NILAI } \\
\text { ISM }\end{array}$ & $\begin{array}{l}0.3636 \\
36364\end{array}$ & $\begin{array}{l}0.3636 \\
36364\end{array}$ & $\begin{array}{l}1.3698 \\
63014\end{array}$ & $\begin{array}{l}0.9523 \\
80952\end{array}$ & $\begin{array}{c}0.4048 \\
583\end{array}$ & 1 & 2.71 \\
\hline $\begin{array}{c}\text { NILAI } \\
\text { NS }\end{array}$ & $\begin{array}{c}0.3184 \\
71338\end{array}$ & $\begin{array}{c}0.3184 \\
71338\end{array}$ & $\begin{array}{c}0.6802 \\
72109\end{array}$ & $\begin{array}{l}0.3333 \\
33333\end{array}$ & $\begin{array}{c}0.5050 \\
50505\end{array}$ & $\begin{array}{c}0.3690 \\
0369\end{array}$ & 1 \\
\hline Jumlah & $\begin{array}{r}3.1263 \\
92564\end{array}$ & $\begin{array}{r}4.5000 \\
76774\end{array}$ & $\begin{array}{r}12.581 \\
28788\end{array}$ & $\begin{array}{r}9.8129 \\
07268\end{array}$ & $\begin{array}{r}9.7099 \\
08805\end{array}$ & $\begin{array}{r}10.799 \\
00369\end{array}$ & 15.3 \\
\hline
\end{tabular}

Tabel V

Normalisasi Matriks Subkriteria Nilai Mata Kuliah

\begin{tabular}{|c|c|c|c|c|c|c|c|}
\hline & $\begin{array}{c}\text { NILAI } \\
\text { ISD }\end{array}$ & $\begin{array}{c}\text { NILAI } \\
\text { EDM }\end{array}$ & $\begin{array}{c}\text { NILAI } \\
\text { TEC }\end{array}$ & $\begin{array}{c}\text { NILAI } \\
\text { ERP }\end{array}$ & $\begin{array}{c}\text { NILAI } \\
\text { EA }\end{array}$ & $\begin{array}{c}\text { NILAI } \\
\text { ISM }\end{array}$ & $\begin{array}{c}\text { NILAI } \\
\text { NS }\end{array}$ \\
\hline NILAI & 0.3198 & 0.4222 & 0.3314 & 0.2955 & 0.3089 & 0.2546 & 0.2052 \\
ISD & 57465 & 15019 & 44606 & 29135 & 62737 & 53122 & 28758 \\
\hline NILAI & 0.1683 & 0.2222 & 0.2861 & 0.2282 & 0.2832 & 0.2250 & 0.1307 \\
EDM & 46034 & 18431 & 39228 & 7078 & 15842 & 20758 & 18954 \\
\hline NILAI & 0.0767 & 0.0532 & 0.0794 & 0.1538 & 0.0937 & 0.0675 & 0.0960 \\
TEC & 04428 & 89792 & 83119 & 78964 & 18697 & 98829 & 78431 \\
\hline NILAI & 0.1102 & 0.0766 & 0.0526 & 0.1019 & 0.1174 & 0.0972 & 0.1960 \\
ERP & 95678 & 27045 & 37827 & 06598 & 0584 & 31192 & 78431 \\
\hline NILAI & 0.1066 & 0.0740 & 0.0873 & 0.0893 & 0.1029 & 0.2287 & 0.1294 \\
EA & 19155 & 7281 & 44087 & 91753 & 87579 & 24804 & 11765 \\
\hline NILAI & 0.1163 & 0.0808 & 0.1088 & 0.0970 & 0.0416 & 0.0926 & 0.1771 \\
ISM & 11805 & 06702 & 80985 & 53903 & 95376 & 01135 & 24183 \\
\hline NILAI & 0.1018 & 0.0707 & 0.0540 & 0.0339 & 0.0520 & 0.0341 & 0.0653 \\
NS & 65435 & 70201 & 70149 & 68866 & 13929 & 70161 & 59477 \\
\hline
\end{tabular}

Tabel VI

Vektor Eigen Subkriteria Nilai Mata Kuliah

\begin{tabular}{|c|c|c|}
\hline $\begin{array}{c}\text { Subkriteria Nilai Mata } \\
\text { Kuliah }\end{array}$ & Jumlah & $\begin{array}{c}\text { Vektor Eigen yang } \\
\text { dinormalkan }\end{array}$ \\
\hline NILAI ISD & 2.137890842 & 0.305412977 \\
\hline NILAI EDM & 1.543930028 & 0.220561433 \\
\hline NILAI TEC & 0.620752259 & 0.088678894 \\
\hline NILAI ERP & 0.752182612 & 0.107454659 \\
\hline NILAI EA & 0.818551952 & 0.116935993 \\
\hline NILAI ISM & 0.71447409 & 0.102067727 \\
\hline NILAI NS & 0.412218217 & 0.058888317 \\
\hline
\end{tabular}

Tabel VII

Tabel Weight Sum Model Subkriteria Nilai Mata Kuliah

\begin{tabular}{|c|c|}
\hline Subkriteria Nilai Mata Kuliah & WSM \\
\hline NILAI ISD & 2.222292742 \\
\hline NILAI EDM & 1.628622751 \\
\hline NILAI TEC & 0.644555401 \\
\hline NILAI ERP & 0.764695985 \\
\hline NILAI EA & 0.852674757 \\
\hline NILAI ISM & 0.724076702 \\
\hline NILAI NS & 0.419262039 \\
\hline Jumlah & 7.256180378 \\
\hline
\end{tabular}

Selanjutnya menghitung nilai konsistensi indeks (CI) dan nilai konsistensi rasio (CR) dengan menggunakan rumus berikut:

$C I=\frac{\text { Kmaksimum }-n}{\mathrm{n}-1}$
$C R=\frac{C I}{\mathrm{RI}}$

Maka nilai konsistensi indeks untuk subkriteria nilai mata kuliah adalah,

$$
C I=\frac{(7.256180378)-7}{7-1}=0.04269673
$$

Untuk $\mathrm{n}=7, \mathrm{RI}=1.32$ maka nilai konsistensi rasio untuk subkriteria nilai mata kuliah adalah,

$$
C R=\frac{0.04269673}{1.32}=0.032346007
$$

Karena nilai $\mathrm{CR}=0.032346007<0.1$ maka preferensi nilai subkriteria mata kuliah konsisten. Untuk menentukan bobot untuk subkriteria mata kuliah didapatkan dengan membagi nilai kolom WSM dengan jumlah nilai kolom WSM. Maka nilai bobot untuk setiap subkriteria nilai mata kuliah dapat dilihat pada Tabel VIII. 


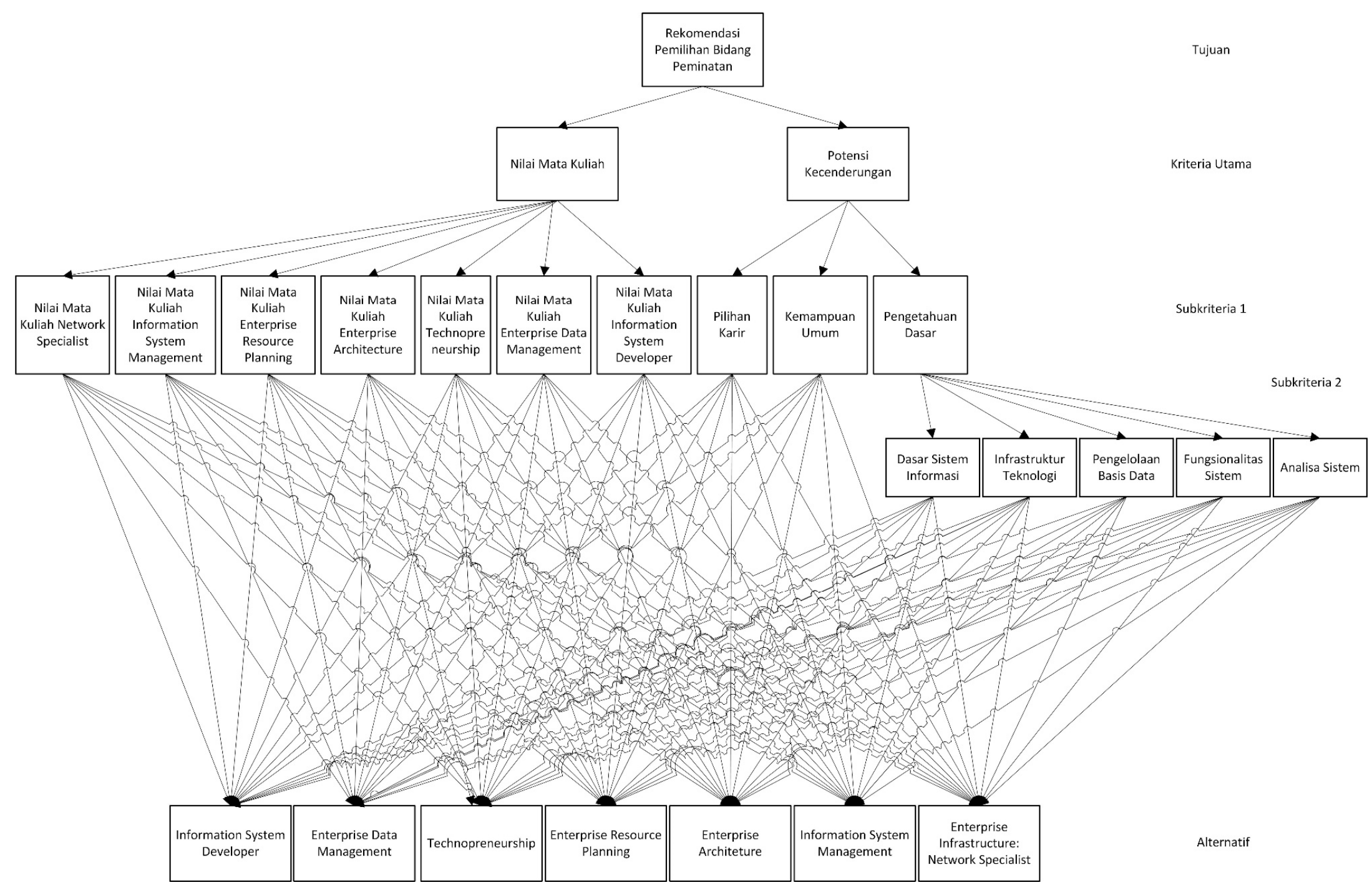

Gambar 1 Hirarki kriteria keputusan

Pembobotan Kriteria Sistem Pendukung Keputusan Pemilihan Bidang Peminatan Menggunakan Metode Analytic Hierarchy Process (Studi Kasus: Program Studi Sistem Informasi Universitas Telkom) 
Tabel VIII

Bobot Subkriteria Nilai Mata Kuliah

\begin{tabular}{|c|c|}
\hline Subkriteria Nilai Mata Kuliah & Bobot \\
\hline NILAI ISD & 0.306262059 \\
\hline NILAI EDM & 0.224446288 \\
\hline NILAI TEC & 0.08882847 \\
\hline NILAI ERP & 0.105385471 \\
\hline NILAI EA & 0.117510138 \\
\hline NILAI ISM & 0.099787583 \\
\hline NILAI NS & 0.057779991 \\
\hline
\end{tabular}

b) Menghitung nilai bobot untuk subkriteria potensi kecenderungan

Langkah pertama yang dilakukan adalah membuat matriks perbandingan untuk subkriteria potensi kecenderungan seperti pada Tabel IX. Lalu menghitung normalisasi matriks dengan cara membagi nilai masing-masing kolom dengan jumlah kolom terkait pada Tabel X.

Tabel IX

Tabel Perbandingan Subkriteria Potensi Kecenderungan

\begin{tabular}{|c|c|c|c|}
\hline & Karir & $\begin{array}{c}\text { Pengetahuan } \\
\text { Dasar }\end{array}$ & $\begin{array}{c}\text { Kemampuan } \\
\text { Umum }\end{array}$ \\
\hline Karir & 1 & 2.42 & 2.06 \\
\hline $\begin{array}{c}\text { Pengeahuan } \\
\text { Dasar }\end{array}$ & 0.41322314 & 1 & 2 \\
\hline $\begin{array}{c}\text { Kemampuan } \\
\text { Umum }\end{array}$ & 0.485436893 & 0.5 & 1 \\
\hline Jumlah & 1 & 2.42 & 2.06 \\
\hline
\end{tabular}

Tabel X

Normalisasi Matriks Subkriteria Potensi Kecenderungan

\begin{tabular}{|c|c|c|c|}
\hline & Karir & $\begin{array}{c}\text { Pengetahuan } \\
\text { Dasar }\end{array}$ & $\begin{array}{c}\text { Kemampuan } \\
\text { Umum }\end{array}$ \\
\hline Karir & 0.526687233 & 0.617346939 & 0.407114625 \\
\hline $\begin{array}{c}\text { Pengetahuan } \\
\text { Dasar }\end{array}$ & 0.217639353 & 0.255102041 & 0.395256917 \\
\hline $\begin{array}{c}\text { Kemampuan } \\
\text { Umum }\end{array}$ & 0.255673414 & 0.12755102 & 0.197628458 \\
\hline
\end{tabular}

Dilanjutkan dengan menghitung nilai vektor eigen dan vektor eigen yang dinormalkan subkriteria potensi kecenderungan pada Tabel XI. Nilai vektor eigen didapatkan dengan menghitung rata-rata bobot relatif setiap baris. Untuk menghitung bobot dari subkriteria potensi kecenderungan diperlukan nilai weighted sum model (WSM) yang didapatkan dengan melakukan perkalian matriks pada baris matriks perbandingan berpasangan dengan kolom vektor eigen yang dinormalkan pada Tabel XII.

Tabel XI

Vektor Eigen Subkriteria Potensi Kecenderungan

\begin{tabular}{|c|c|c|}
\hline $\begin{array}{c}\text { Subkriteria Potensi } \\
\text { Kecenderungan }\end{array}$ & Jumlah & $\begin{array}{c}\text { Vektor Eigen yang } \\
\text { dinormalkan }\end{array}$ \\
\hline Karir & 1.551148797 & 0.517049599 \\
\hline Pengetahuan Dasar & 0.86799831 & 0.28933277 \\
\hline Kemampuan Umum & 0.580852893 & 0.193617631 \\
\hline
\end{tabular}

Tabel XII

Tabel Weight Sum Method Subkriteria Nilai Mata Kuliah

\begin{tabular}{|c|c|}
\hline Subkriteria Potensi Kecenderungan & WSM \\
\hline Karir & 1.616087222 \\
\hline Pengetahuan Dasar & 0.890224891 \\
\hline Kemampuan Umum & 0.589278967 \\
\hline Jumlah & 3.095591081 \\
\hline
\end{tabular}

Selanjutnya menghitung nilai konsistensi indeks (CI) dan nilai konsistensi rasio (CR)

$$
C I=\frac{(3.095591081)-3}{3-1}=0.04779554
$$

Untuk $\mathrm{n}=3$, $\mathrm{RI}=0.85$ maka nilai konsistensi rasio untuk subkriteria nilai mata kuliah adalah,

$$
C R=\frac{0.04779554}{0.58}=0.082406104
$$

Karena nilai $\mathrm{CR}=0.082406104<0.1$ maka preferensi nilai subkriteria potensi kecenderungan konsisten. Untuk menentukan bobot untuk subkriteria potensi kecenderungan didapatkan dengan membagi nilai kolom WSM dengan jumlah nilai kolom WSM. Maka nilai bobot untuk setiap subkriteria potensi kecenderungan dapat dilihat pada Tabel XIII,

Tabel XIII

Bobot Subkriteria Potensi Kecenderungan

\begin{tabular}{|c|c|}
\hline Subkriteria Potensi Kecenderungan & Bobot \\
\hline Karir & 0.522060951 \\
\hline Pengetahuan Dasar & 0.287578323 \\
\hline Kemampuan Umum & 0.190360726 \\
\hline
\end{tabular}

c) Menghitung nilai bobot subkriteria pengetahuan dasar Langkah pertama yang dilakukan adalah membuat matriks perbandingan untuk subkriteria pengetahuan dasar paad Tabel XIV. Lalu menghitung normalisasi matriks dengan cara membagi nilai masing-masing kolom dengan jumlah kolom terkait pada Tabel XV.

Tabel XIV

Matriks Perbandingan Subkriteria Pengetahuan Dasar

\begin{tabular}{|c|c|c|c|c|c|}
\hline & $\begin{array}{c}\text { Dasar } \\
\text { SI }\end{array}$ & $\begin{array}{c}\text { Fungsio } \\
\text { nalitas }\end{array}$ & $\begin{array}{c}\text { Pengelola } \\
\text { an data }\end{array}$ & $\begin{array}{c}\text { Analisa } \\
\text { sistem }\end{array}$ & $\begin{array}{c}\text { Infrastru } \\
\text { ktur TI }\end{array}$ \\
\hline Dasar SI & 1 & 2.03 & 3.42 & 2.9 & 2.02 \\
\hline $\begin{array}{c}\text { Fungsiona } \\
\text { litas }\end{array}$ & $\begin{array}{c}0.49261 \\
0837\end{array}$ & 1 & 2 & $\begin{array}{c}0.55991 \\
0414\end{array}$ & $\begin{array}{c}0.989119 \\
683\end{array}$ \\
\hline $\begin{array}{c}\text { Pengelola } \\
\text { an data }\end{array}$ & $\begin{array}{c}0.29239 \\
7661\end{array}$ & 0.5 & 1 & $\begin{array}{c}0.41152 \\
2634\end{array}$ & $\begin{array}{c}1.052631 \\
579\end{array}$ \\
\hline $\begin{array}{c}\text { Analisa } \\
\text { sistem }\end{array}$ & $\begin{array}{c}0.34482 \\
7586\end{array}$ & 1.786 & 2.43 & 1 & 2.9 \\
\hline $\begin{array}{c}\text { Infrastrukt } \\
\text { ur TI }\end{array}$ & $\begin{array}{c}0.49504 \\
9505\end{array}$ & 1.011 & 0.95 & $\begin{array}{c}0.34482 \\
7586\end{array}$ & 1 \\
\hline $\begin{array}{c}\text { Jumlah } \\
\text { Jumlah }\end{array}$ & $\begin{array}{c}5.62488 \\
5589\end{array}$ & 6.327 & 9.8 & $\begin{array}{c}5.21626 \\
0634\end{array}$ & $\begin{array}{c}7.961751 \\
262\end{array}$ \\
\hline
\end{tabular}


Tabel XV

Normalisasi Matriks Subkriteria Pengetahuan Dasar

\begin{tabular}{|c|c|c|c|c|c|}
\hline & $\begin{array}{c}\text { Dasar } \\
\text { SI }\end{array}$ & $\begin{array}{c}\text { Fungsio } \\
\text { nalitas }\end{array}$ & $\begin{array}{c}\text { Pengelol } \\
\text { aan data }\end{array}$ & $\begin{array}{c}\text { Analisa } \\
\text { sistem }\end{array}$ & $\begin{array}{c}\text { Infrastru } \\
\text { ktur TI }\end{array}$ \\
\hline Dasar SI & 0.3809 & 0.3208 & 0.348979 & 0.55595 & 0.25371 \\
& 68985 & 47163 & 592 & 3815 & 3025 \\
\hline Fungsion & 0.1876 & 0.1580 & 0.204081 & 0.10733 & 0.12423 \\
alitas & 69451 & 5279 & 633 & 9424 & 3934 \\
\hline Pengelol & 0.1113 & 0.0790 & 0.102040 & 0.07889 & 0.13221 \\
aan data & 9444 & 26395 & 816 & 2268 & 1061 \\
\hline Analisa & 0.1313 & 0.2822 & 0.247959 & 0.19170 & 0.36424 \\
sistem & 68616 & 82282 & 184 & 8212 & 1472 \\
\hline Infrastru & 0.1885 & 0.1597 & 0.096938 & 0.06610 & 0.12560 \\
ktur TI & 98508 & 9137 & 776 & 628 & 0508 \\
\hline
\end{tabular}

Dilanjutkan dengan menghitung nilai vektor eigen dan vektor eigen yang dinormalkan subkriteria pengetahuan dasar pada Tabel XVI, nilai vektor eigen yang dinormalkan didapat dengan cara membagi jumlah nilai pada baris dengan jumlah ukuran matriks. Nilai vektor eigen didapatkan dengan menghitung rata-rata bobot relatif setiap baris.

Tabel XVI

Vektor Eigen Subkriteria Pengetahuan Dasar

\begin{tabular}{|c|c|c|}
\hline $\begin{array}{c}\text { Subkriteria Pengetahuan } \\
\text { Dasar }\end{array}$ & Jumlah & $\begin{array}{c}\text { Vektor Eigen yang } \\
\text { dinormalkan }\end{array}$ \\
\hline Dasar SI & $\begin{array}{c}1.8604625 \\
81\end{array}$ & 0.372092516 \\
\hline Fungsionalitas & $\begin{array}{c}0.7813772 \\
32\end{array}$ & 0.156275446 \\
\hline Pengelolaan data & $\begin{array}{c}0.5035649 \\
8\end{array}$ & 0.100712996 \\
\hline Analisa sistem & $\begin{array}{c}1.2175597 \\
66\end{array}$ & 0.243511953 \\
\hline Infrastruktur TI & $\begin{array}{c}0.6370354 \\
41\end{array}$ & 0.127407088 \\
\hline
\end{tabular}

Untuk menghitung bobot dari subkriteria pengetahuan dasar diperlukan nilai weighted sum model (WSM) yang didapatkan dengan melakukan perkalian matriks pada baris matriks perbandingan berpasangan dengan kolom vektor eigen yang dinormalkan pada Tabel XVII.

Tabel XVII

Weight Sum Method Subkriteria Pengetahuan Dasar

\begin{tabular}{|c|c|}
\hline Subkriteria Pengetahuan Dasar & WSM \\
\hline Dasar SI & 1.997317101 \\
\hline Fungsionalitas & 0.803363982 \\
\hline Pengelolaan data & 0.521973105 \\
\hline Analisa sistem & 1.265140801 \\
\hline Infrastruktur TI & 0.649252766 \\
\hline Jumlah & 5.237047755 \\
\hline
\end{tabular}

Selanjutnya menghitung nilai konsistensi indeks (CI) dan nilai konsistensi rasio (CR). Nilai konsistensi indeks untuk subkriteria pengetahuan dasar adalah

$$
C I=\frac{5.237047755-5}{5-1}=0.059261939
$$

Untuk $\mathrm{n}=5, \mathrm{RI}=1.12$ maka nilai konsistensi rasio untuk subkriteria pengetahuan dasar adalah,

$$
C R=\frac{0.059261939}{1.12}=0.052912445
$$

Karena nilai $\mathrm{CR}=0.052912445<0.1$ maka preferensi nilai subkriteria pengetahuan dasar konsisten. Untuk menentukan bobot untuk subkriteria pengetahuan dasar didapatkan dengan membagi nilai kolom WSM dengan jumlah nilai kolom WSM. Maka nilai bobot untuk setiap subkriteria nilai mata kuliah dapat dilihat pada Tabel XVIII.

Tabel XVIII

Bobot Subkriteria Pengetahuan Dasar

\begin{tabular}{|c|c|}
\hline Subkriteria Pengetahuan Dasar & Bobot \\
\hline Dasar SI & 0.206592352 \\
\hline Fungsionalitas & 0.197851689 \\
\hline Pengelolaan data & 0.199471459 \\
\hline Analisa sistem & 0.199957055 \\
\hline Infrastruktur TI & 0.196127445 \\
\hline
\end{tabular}

d) Menentukan nilai bobot akhir kriteria

Untuk mendapatkan nilai akhir bobot kriteria adalah dengan mengalikan kolom nilai bobot kriteria utama dengan nilai pada kolom bobot sub kriteria. Hasil perkalian akan menjadi nilai pada kolom bobot akhir kriteria, untuk kolom bobot sub kriteria yang tidak memiliki nilai maka tidak perlu dimasukkan kedalam perhitungan nilainya. Berikut Tabel bobot akhir untuk masing-masing kriteria pada Tabel XIX.

\begin{tabular}{|c|c|c|c|c|c|}
\hline \multicolumn{6}{|c|}{ Bobot Akhir Kriteria } \\
\hline $\begin{array}{l}\text { Kode } \\
\text { kriteria }\end{array}$ & $\begin{array}{l}\text { Nama } \\
\text { kriteria }\end{array}$ & $\begin{array}{c}\text { Bobot } \\
\text { kriteria } \\
\text { utama }\end{array}$ & $\begin{array}{c}\text { Bobot } \\
\text { subkriteria }\end{array}$ & $\begin{array}{c}\text { Bobot } \\
\text { subkriteria }\end{array}$ & $\begin{array}{l}\text { Bobot } \\
\text { akhir } \\
\text { kriteria } \\
(\mathrm{w})\end{array}$ \\
\hline $\mathrm{C} 1$ & Nilai ISD & 0.65 & $\begin{array}{c}0.3062620 \\
59\end{array}$ & & $\begin{array}{c}0.19907 \\
0338\end{array}$ \\
\hline $\mathrm{C} 2$ & Nilai EDM & 0.65 & $\begin{array}{c}0.2244462 \\
88\end{array}$ & & $\begin{array}{c}0.14589 \\
0087\end{array}$ \\
\hline C3 & Nilai TEC & 0.65 & $\begin{array}{c}0.0888284 \\
7\end{array}$ & & $\begin{array}{c}0.05773 \\
8506\end{array}$ \\
\hline $\mathrm{C} 4$ & Nilai ERP & 0.65 & $\begin{array}{c}0.1053854 \\
71\end{array}$ & & $\begin{array}{c}0.06850 \\
0556\end{array}$ \\
\hline $\mathrm{C} 5$ & Nilai EA & 0.65 & $\begin{array}{c}0.1175101 \\
38\end{array}$ & & $\begin{array}{c}0.07638 \\
159\end{array}$ \\
\hline C6 & Nilai ISM & 0.65 & $\begin{array}{c}0.0997875 \\
83 \\
\end{array}$ & & $\begin{array}{c}0.06486 \\
1929 \\
\end{array}$ \\
\hline $\mathrm{C} 7$ & Nilai NS & 0.65 & $\begin{array}{c}0.0577799 \\
91 \\
\end{array}$ & & $\begin{array}{c}0.03755 \\
6994 \\
\end{array}$ \\
\hline $\mathrm{C} 8$ & $\begin{array}{c}\text { Pilihan } \\
\text { Karir }\end{array}$ & 0.35 & $\begin{array}{c}0.5220609 \\
51\end{array}$ & & $\begin{array}{c}0.18272 \\
1333\end{array}$ \\
\hline C9 & $\begin{array}{l}\text { Kemampuan } \\
\text { Umum }\end{array}$ & 0.35 & $\begin{array}{c}0.1903607 \\
26\end{array}$ & & $\begin{array}{c}0.06662 \\
6254\end{array}$ \\
\hline
\end{tabular}

Tabel XIX

Pembobotan Kriteria Sistem Pendukung Keputusan Pemilihan Bidang Peminatan Menggunakan Metode 


\begin{tabular}{|c|c|c|c|c|c|}
\hline $\begin{array}{l}\text { Kode } \\
\text { kriteria }\end{array}$ & $\begin{array}{l}\text { Nama } \\
\text { kriteria }\end{array}$ & $\begin{array}{l}\text { Bobot } \\
\text { kriteria } \\
\text { utama }\end{array}$ & $\begin{array}{c}\text { Bobot } \\
\text { subkriteria }\end{array}$ & $\begin{array}{c}\text { Bobot } \\
\text { subkriteria }\end{array}$ & $\begin{array}{c}\text { Bobot } \\
\text { akhir } \\
\text { kriteria } \\
(\mathrm{w}) \\
\end{array}$ \\
\hline C10 & $\begin{array}{c}\text { Pengetahuan } \\
\text { : dasar sistem } \\
\text { informasi }\end{array}$ & 0.35 & $\begin{array}{c}0.2875783 \\
23 \\
\end{array}$ & $\begin{array}{c}0.2065923 \\
52 \\
\end{array}$ & $\begin{array}{c}0.02079 \\
4019 \\
\end{array}$ \\
\hline C11 & $\begin{array}{c}\text { Pengetahuan } \\
\text { fungsionalita } \\
\text { s SI } \\
\end{array}$ & 0.35 & $\begin{array}{c}0.2875783 \\
23\end{array}$ & $\begin{array}{c}0.1978516 \\
89 \\
\end{array}$ & $\begin{array}{c}0.01991 \\
425\end{array}$ \\
\hline $\mathrm{C} 12$ & $\begin{array}{c}\text { Pengetahuan } \\
\text { : pengelolaan } \\
\text { data }\end{array}$ & 0.35 & $\begin{array}{c}0.2875783 \\
23\end{array}$ & $\begin{array}{c}0.1994714 \\
59\end{array}$ & $\begin{array}{c}0.02007 \\
7284\end{array}$ \\
\hline C13 & $\begin{array}{c}\text { Pengetahuan } \\
\text { : analisa } \\
\text { sistem }\end{array}$ & 0.35 & $\begin{array}{c}0.2875783 \\
23\end{array}$ & $\begin{array}{c}0.1999570 \\
55\end{array}$ & $\begin{array}{c}0.02012 \\
616\end{array}$ \\
\hline C14 & $\begin{array}{c}\text { Pengetahuan } \\
: \\
\text { infrastruktur } \\
\text { teknologi }\end{array}$ & 0.35 & $\begin{array}{c}0.2875783 \\
23\end{array}$ & $\begin{array}{c}0.1961274 \\
45\end{array}$ & $\begin{array}{c}0.01974 \\
0701\end{array}$ \\
\hline
\end{tabular}

V. KESIMPULAN

Pada penelitian ini terlihat bahwa penerapan metode AHP dalam menentukan nilai bobot kriteria, dapat dihitung menggunakan matriks perbandingan berpasangan. Dari penelitian ini dihasilkan nilai bobot untuk kriteria nilai mata kuliah sebesar $65 \%$, dan kriteria potensi kecenderungan sebesar 35\%. Selain didapatkan nilai bobot utama, penelitian ini juga menghitung nilai bobot untuk setiap subkriteria. Pembobotan yang didasarkan pada penilaian subjektif mendapatkan nilai konsistensi kurang dari $10 \%$, sehingga penilaian dapat diterima dan digunakan. Hasil pembobotan dapat digunakan dalam penelitian pemodelan sistem pendukung keputusan pemilihan bidang peminatan menggunakan metode SAW.

\section{DAFTAR PUSTAKA}

[1] Saaty, T. L.,Decision Making With The Analytical Hierarchy Process, International Journal of Services Sciences, Volume 1, 2008, pp. 83 - 98.

[2] Khairinisa, H., Wirayuda, T.A.B. and Saadah, S., "APLIKASI PEMBANTU PENGOLAHAN INFORMASI PEMINATAN TOPIK TA DAN KK BAGI MAHASISWA FAKULTAS INFORMATIKA INSTITUT TEKNOLOGI TELKOM", 2012.

[3] Suryaningrum, K. M.. "Sistem Pendukung Keputusan untuk Penjurusan Mahasiswa (Studi Kasus : Teknik Informatika Universitas Bunda Mulia)". SENTIKA 2015, 2015, pp. 109-120.

[4] Wilan, U., Widyastuti, L., \& Nugraha, F. (2016). IDENTIFIKASI KEY POSITION DENGAN METODE ANALYTIC HIERARCHY PROCESS (AHP) DAN KRITERIA PROFIL KOMPETENSI TALENT KEY POSITION PADA PT. INDUSTRI TELEKOMUNIKASI INDONESIA. Jurnal Rekayasa Sistem \& Industri (JRSI), 1(01), 31-36

[5] Moore, J. H., dan Chang, M. G.,, 1980. Design of Decision Support Systems. Volume 12.

[6] Bonczek, R.H., Holsapple, C.W. and Whinston, A.B., 1980. The evolving roles of models in decision support systems. Decision Sciences, 11(2), pp.337-356.Turban, E. et al., 2005. Decision Support Systems and Intelligent
Systems (Sistem Pendukung Keputusan dan Sistem Cerdas). Yogyakarta: Andi Offset.

[7] Turban, E. et al., 2005. Decision Support Systems and Intelligent Systems (Sistem Pendukung Keputusan dan Sistem Cerdas). Yogyakarta: Andi Offset.

[8] Kusrini, 2007. Konsep dan Aplikasi Sistem Pendukung Keputusan. Yogyakarta: Penerbit Andi.

[9] Abdelhamid, Ramadan, and Z. Eldin. "A decision support system for performance evaluation." IJCA Special Issue on Computational Intelligence \& Information Security CIIS 2012, 2012, pp. 1-8.

[10] E.W.L. Cheng H. Li, (2003),"Utility of consistency measure in the analytic hierarchy process", Construction Innovation, Vol. 3 Iss 4 pp. $231-247$.

[11] Benítez, J., Delgado-Galván, X., Gutiérrez, J.A. and Izquierdo, J. "Balancing consistency and expert judgment in AHP". Mathematical and Computer Modelling, 54(7), 2011, pp.1785-1790.

[12] Kittur, J., 2015, June. Optimal generation evaluation using SAW, WP, AHP and PROMETHEE multi-Criteria decision making techniques. In Advancements in Power and Energy (TAP Energy), 2015 International Conference on (pp. 304-309). IEEE.

[13] Afshari, A., Mojahed, M. and Yusuff, R.M. "Simple additive weighting approach to personnel selection problem". International Journal of Innovation, Management and Technology, Volume 1, Number 5, 2010 , pp.511.

[14] Hafiyusholeh, M., Asyhar, A.H. and Komaria, R. Aplikasi Metode Nilai Eigen Dalam Analytical Hierarchy Process Untuk Memilih Tempat Kerja. Jurnal Matematika "MANTIK", Volume 1, Number 1, 2015, pp.6-16.

[15] Mahendra, Danang, and Noor Azizah. "IMPLEMENTASI FUZZY INFERENCE SYSTEM TSUKAMOTO UNTUK PENENTUAN TOPIK TUGAS AKHIR." Simetris: Jurnal Teknik Mesin, Elektro dan Ilmu Komputer, Volume 7, Number 1, 2016, pp. 337-344. 